\title{
PENGARUH MODEL PEMBELAJARAN PROJECT BASED LEARNING BERBANTUAN MEDIA PEMBELAJARAN PEMBANGKIT LISTRIK TENAGA MIKROHIDRO TERHADAP KEMAMPUAN BERPIKIR KRITIS
}

\section{EFFECT OF PROJECT BASED LEARNING WITH MICROHYDRO POWER PLANTS MEDIA ON CRITICAL THINKING SKILLS}

\author{
Hendrik Pratama ${ }^{1, a}$, Ihtiari Prastyaningrum ${ }^{2, b}$ \\ 1,2Prodi Pendidikan Teknik Elektro, Fakultas Kependidikan dan Ilmu Pendidikan, \\ Universitas PGRI Madiun \\ Jl. Auri, Nomor 6, Madiun 63118, Indonesia \\ e-mail: ${ }^{a}$ pratama@unipma.ac.id, bihtiari.prastya@unipma.ac.id
}

\begin{abstract}
Abstrak
Penelitian ini bertujuan untuk mengetahui pengaruh pembelajaran Project Based Learning berbantuan media pembelajaran pembangkit listrik mikrohidro terhadap kemampuan berpikir kritis. Penelitian dilaksanakan di Program Studi Pendidikan Teknik Elektro IKIP PGRI Madiun pada mahasiswa Semester II yang mengikuti mata kuliah Fisika Teknik. Desain penelitian menggunakan sistem one group pretest posttest design. Pengumpulan data dilakukan dalam bentuk observasi dan tes pilihan ganda. Instrumen penelitian berupa silabus, Rencana Pelaksanaan Pembelajaran (RPP), dan Lembar Kerja. Hasil penelitian menunjukkan data bahwa perhitungan N-gain ternormalisasi diperoleh rata-rata kenaikan kemampuan berpikir kritis dari 20 orang peserta didik adalah 0,45 (kategori sedang). Sedangkan hasil analisis data dengan uji $t$ (t-test) menunjukkan bahwa terdapat perbedaan nilai kemampuan berpikir kritis peserta didik sebelum dan sesudah diberikan pembelajaran dengan model Project Based Learning. Nilai rerata mean diperoleh rerata nilai postes $(81,44)$ lebih tinggi daripada nilai pretes (61,41). Sehingga dapat disimpulkan bahwa penerapan model pembelajaran Project Based Learning berbantuan media pembelajaran pembangkit listrik mikrohidro dapat meningkatkan kemampuan berpikir kritis peserta didik.
\end{abstract}

Kata Kunci: Project Based Learning, Media Pembelajaran, Mikrohidro, Kemampuan Berpikir Kritis

Abstract

This study aims to determine the influence of Project Based Learning assisted by micro hydro power plants as learning media on the ability to think critically. The experiment was conducted toward students in second semester of Electrical Engineering Education Program at Teachers' Training College PGRI Madiun who follow courses of Engineering Physics. The study design used a system of one group pretest posttest design. The data collection was done in the form of observations and multiple-choice tests. The research instrument were the syllabus, lesson plan (RPP), and Worksheet. The results showed the data of the calculated average normalized N-gain increased in critical thinking skill of 20 learners is 0.45 (medium category). While the results of the analyzed data with t test showed that there are differences in

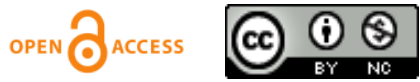


the value of the critical thinking skill of students before and after learning the model of Project Based Learning. The average value obtained by the posttest mean value (81.44) is higher than the value of the pretest (61.41). It can be concluded that the application of Project Based Learning model assisted by micro hydro power plants as learning media can increase the critical thinking skill of learners.

Keywords: Project Based Learning, Microhydro Learning Media, Critical Thinking Skill

Copyright@2016 Jurnal Penelitian Fisika dan Aplikasinya (JPFA)

\section{PENDAHULUAN}

Sesuai dengan Peraturan Pemerintah Nomor 81A Tahun 2013 [1], bahwa proses pembelajaran dituntut berpusat pada peserta didik, dapat mengembangkan kreativitas anak, bermuatan nilai etika, estetika, logika, dan kinestetika, menciptakan kondisi menyenangkan dan menantang, serta menyediakan pengalaman belajar yang beragam. Pembelajaran Berbasis Proyek (Project Based Learning) merupakan metode pembelajaran yang menggunakan proyek sebagai media pembelajaran dan dinilai sejalan dengan peraturan pemerintah. Peserta didik dituntut melakukan eksplorasi, penilaian, interpretasi, sintesis, dan informasi untuk menghasilkan berbagai bentuk hasil belajar. Pendidik hanya berperan sebagai fasilitator.

Pembelajaran Berbasis Proyek bertujuan memecahkan permasalahan dengan mengangkat dari peristiwa sehari-hari di mana peserta didik memiliki kesempatan untuk menemukan pengetahuan baru dihubungkan dengan pengetahuan prasyarat. Menurut Birgili [2] dalam pembelajaran berbasis proyek, peserta didik dituntut berpartisipasi aktif untuk menciptakan solusi inovatif terhadap masalah melalui pengalaman yang dialami. Pembelajaran berbasis proyek menuntut belajar yang bersifat kolaboratif. Hal tersebut tentunya memberikan peluang untuk meningkatkan pemahaman konseptual dan kecakapan teknik. Menuntut adanya umpan balik internal yang dapat menajamkan keterampilan berpikir. Langkah-langkah dalam penerapan model Pembelajaran Berbasis Proyek (MPBP) yang diterapkan dalam penelitian ini mengacu pada langkah-langkah yang diadaptasi dari Mergendoller, et al., [3], yang meliputi: (1) perencanaan proyek (project planning), (2) pelaksanaan proyek (project launch), (3) penyelidikan terbimbing dan pembuatan produk (guided inquiry and product creation), dan (4) kesimpulan proyek (Project Conclution).

Pembelajaran keterampilan berpikir kritis dapat dilakukan pendidik dengan pembelajaran menggunakan strategi-strategi pembelajaran konstruktivistik yang berpotensi memberdayakan keterampilan berpikir kritis, seperti pembelajaran berbasis proyek. Menurut Ahlam dan Gaber [4], dengan pembelajaran berpikir kritis membuat peserta didik terintervensi untuk meningkatkan rasa ingin tahu dan kematangan. Hal ini terbukti peningkatan statistik total skor rata-rata perolehan pengetahuan dan retensi kelompok eksperimen dari skor total rata-rata perolehan pengetahuan dan retensi kelompok kontrol. Melalui pembelajaran berpikir kritis diharapkan dapat mengintegrasikan kemampuan seperti pengamatan, analisis, penalaran penilaian dan pengambilan keputusan. Pelaksanaannya dapat dilakukan dengan membangun suasana kelas yang dapat menghargai pemikiran dan analisis siswa seperti kegiatan laboratorium, penemuan, pekerjaan rumah, bahkan sampai 
ujian yang mencakup pertanyaan tingkat tinggi.

Pelajaran fisika termasuk kelompok ilmu sains yaitu ilmu yang diperoleh dan dikembangkan berdasarkan eksperimen untuk mencari jawaban atas pertanyaan apa, mengapa, dan bagaimana gejala-gejala alam, khususnya yang berkaitan dengan komposisi, struktur, sifat transformasi, dinamika, dan energitika zat. Fisika sebagai bagian dari mata pelajaran IPA, dipahami sebagai mata pelajaran yang menuntut kegiatan menghitung tingkat tinggi sehingga banyak peserta didik yang takut atau tidak suka dengan pelajaran fisika yang berakibat peserta didik malas untuk belajar. Padahal ilmu fisika yang sarat dengan misteri-misteri semesta itu bisa dikuasai oleh peserta didik dengan mudah. Berdasarkan data, nilai mata kuliah Fisika Teknik mahasiswa di Program Studi Pendidikan Teknik Elektro menunjukkan rerata 68 yang kurang dari standar baik. Media mikrohidro digunakan dalam upaya untuk menstimulus peserta didik pada mata kuliah Fisika Dasar.

Mikrohidro merupakan istilah yang digunakan untuk instalasi pembangkit listrik yang menggunakan energi air. Kondisi air yang bisa dimanfaatkan sebagai sumber daya (resources) penghasil listrik adalah memiliki kapasitas aliran dan ketinggian tertentu dan instalasi. Semakin besar kapasitas aliran maupun ketinggiannya dari istalasi maka semakin besar energi yang bisa dimanfaatkan untuk menghasilkan energi listrik [5]. Melalui media mikrohidro, peserta didik akan belajar merancang media yang bermanfaat bagi lingkungan namun juga akan mendapatkan ilmu dari sisi Fisika seperti konsep energi listrik.

Berdasarkan uraian di atas, penelitian tentang pelaksanaan pembelajaran Project Based
Learning berbantuan media pembelajaran pembangkit listrik mikrohidro terhadap kemampuan berpikir kritis perlu dilakukan sebagai salah satu upaya meningkatkan kemampuan peserta didik, dan menciptakan pembelajaran yang lebih bermakna dan berkualitas bagi peserta didik program pendidikan teknik elektro. Penelitian ini bertujuan untuk mengetahui pengaruh pembelajaran Project Based Learning berbantuan media pembelajaran pembangkit listrik mikrohidro terhadap kemampuan berpikir kritis.

\section{METODE PENELITIAN}

Metode yang di gunakan dalam penelitian ini adalah metode Pre-eksperimen. Menurut Sugiono [6] bahwa penelitian pre-eksperimen hasilnya merupakan variabel dependen bukan semata-mata dipengaruhi oleh variabel independen, tidak adanya variabel kontrol, dan sampel tidak dipilih secara random.

Desain penelitian yang digunakan dalam penelitian ini ialah one group pretest posttest design. Dalam desain ini, sebelum perlakuan diberikan terlebih dahulu sampel diberi pretest (tes awal) dan di akhir pembelajaran sampel diberi posttest (tes akhir). Desain ini digunakan sesuai dengan tujuan yang hendak dicapai yaitu ingin mengetahui peningkatan kemampuan berpikir kritis mahasiswa setelah diterapkan model pembelajaran Project Based Learning.

Sampel yang diambil dalam penelitian ini adalah mahasiswa semester I Program Studi Pendidikan Teknik Elektro yang menempuh mata kuliah Fisika Dasar.

Tahap penelitian ini meliputi tahap persiapan penelitian, tahap pelaksanaan penelitian, dan tahap akhir penelitian yang mengacu pada sintaks pembelajaran Project Based Learning. Variabel dalam penelitian adalah model pembelajaran Project Based Learning. 
Variabel moderator adalah kemampuan berpikir kritis dikateogrikan menjadi dua yaitu tinggi dan rendah.

Data yang diungkap dalam penelitian berupa fakta, pendapat, dan kemampuan dalam bentuk hasil tes dan lembar observasi yang dilakukan oleh pendidik. Pengumpulan data kemampuan berpikir kritis dilakukan dalam bentuk tes pilihan ganda yang diambil pre-test dan post-test. Instrumen pelaksanaan penelitian dalam penelitian ini berupa silabus, Rencana Pelaksanaan Pembelajaran (RPP) dan Lembar Kerja Peserta didik (LKS).

Uji normalitas data menggunakan uji Kolmogorov-Smirnov dan uji homogenitas menggunakan Levene's test yang terdapat pada software SPSS 20. Pengujian hipotesis pada penelitian ini menggunakan uji parametrik. Analisis data dengan uji t (t-test) digunakan untuk mengetahui pengaruh pembelajaran Project Based Learning berbantuan media pembelajaran pembangkit listrik mikrohidro terhadap kemampuan berpikir kritis. Data nilai pretes dan postes juga dianalisis menggunakan gain score. Gain digunakan untuk menunjukkan peningkatan pemahaman atau penguasaan konsep peserta didik setelah pembelajaran dilakukan pendidik.

\section{HASIL PENELITIAN DAN DISKUSI}

Proses pembelajaran yang dilakukan mengacu pada sintak model pembelajaran Project Based Learning. yaitu perencanaan proyek (project planning), (2) pelaksanaan proyek (project launch), (3) penyelidikan terbimbing dan pembuatan produk (guided inquiry and product creation), dan (4) kesimpulan proyek (project conclution).

Pada tahap perencanaan proyek, tiap kelompok diberikan permasalahan terkait pemanfaatan energi air menjadi energi listrik dengan memanfaatkan konsep mikrohidro. Siswa melakukan analisis tentang konsep pembuatan alat mikrohidro baik bersumber dari buku, jurnal, maupun media masa. Tahap pelaksanaan proyek, siswa menentukan lokasi sebagai bentuk aplikasi dan membuat desain alat yang akan dibuat. Tahap penyelidikan terbimbing dan pembuatan produk dilakukan dengan membuat alat sampai bisa digunakan. Gambar 1 adalah contoh desain alat mikrohidro. Tahap akhir dari pembelajaran adalah kesimpulan proyek. Pada tahap ini siswa harus bisa menjelaskan dan mengaitkan anatar konsep proyek dengan materi pembelajaran.



Gambar 1. Desain Rancangan Mikrohidro

Tabel 1. Deskripsi Data Tes Kemampuan Berpikir Kritis

\begin{tabular}{lccccc}
\hline Jenis Tes & Jumlah siswa & Mean & $\begin{array}{c}\text { Standar } \\
\text { Deviasi }\end{array}$ & Maksimum & Minimum \\
\hline Pretes & 20 & 64,31 & 7,890 & 87 & 60 \\
Postes & 20 & 81,34 & 8,654 & 93 & 50 \\
\hline
\end{tabular}


Berdasarkan Tabel 1. dapat dilihat bahwa rerata sebelum diberikan pembelajaran dengan modul adalah 64,31 dengan standar deviasi 7,89 ; nilai minimum yang diperoleh adalah 60; dan nilai maksimum yang diperoleh 87. Mean sesudah diberikan modul pembelajaran adalah 81,34 dengan standar deviasi 8,654; nilai maksimum yang diperoleh adalah 93; dan nilai minimum yang diperoleh 60. Nilai pretes dan postes tersebut kemudian dihitung tingkat kenaikan hasil belajarnya untuk mengetahui efektifitas pembelajaran dengan model pembelajaran
Project Based Learning. Rumus yang digunakan adalah rumus $\mathrm{N}$-gain ternormalisasi. Berdasarkan hasil perhitungan $\mathrm{N}$-gain ternormalisasi diperoleh rata-rata kenaikan hasil belajar dari 20 orang siswa adalah 0,45. Menurut kriteria Hake [7] nilai tersebut menunjukkan bahwa kenaikan hasil belajar peserta didik dalam kategori "sedang". Setelah dilakukan perhitungan $\mathrm{N}$-gain ternormalisasi, hasil belajar selanjutnya diuji prasyarat sebelum dilakukan uji t.

Tabel 2. Ringkasan Hasil Analisis Nilai Pretes dan Postes

\begin{tabular}{rllll}
\hline Uji & \multicolumn{1}{c}{ Jenis Uji } & Hasil & Keputusan & Kesimpulan \\
\hline Normalitas & Kolmogorof-S & Sig pretes $=0,621$ & Ho diterima & Data normal \\
& mirnov & Sig postes $=0,502$ & & \\
Homogenitas & Levene's test & Sig 0.372 & Ho diterima & Data homogen \\
Hasil Pretes-Postes & Paired sample & thitung $=-8,464$ & Ho ditolak & Hasil tidak sama \\
& t-test & $\mathrm{p}=0,00$ & & (ada beda) \\
\hline
\end{tabular}

Berdasarkan ringkasan hasil analisis nilai peserta didik diketahui bahwa normalitas data yang diuji dengan Kolmogorof-Smirnov, diperoleh taraf signifikansi sebesar 0,621 untuk pretes dan 0,502 untuk postes, kedua nilai tersebut lebih besar dari $\alpha=0,05$ sehingga Ho diterima, yang berarti data nilai pretes dan postes berdistribusi normal. Uji homogenitas diperoleh taraf signifikansi sebesar 0,372 yang berarti signifikansi $>0,05$ sehingga Ho diterima, yang berarti variansi setiap sampel sama (homogen).

Data nilai pretes dan postes yang telah diketahui bahwa distribusinya normal dan homogen selanjutnya dianalisis dengan uji Paired Sample t-test. Berdasarkan perhitungan diperoleh $\mathrm{t}$ hitung $=-8,464$ dengan probabilitas sebesar $0,000(p<0,05)$, maka Ho ditolak. Hal tersebut menunjukkan bahwa terdapat perbedaan nilai kemampuan berpikir kritis peserta didik sebelum diberikan pembelajaran dengan nilai kemampuan berpikir kritis peserta didik setelah diberikan pembelajaran dengan model Project Based Learning. Merujuk pada hasil analisis tersebut maka dapat disimpulkan bahwa pemberian pembelajaran Project Based Learning berbantuan media pembelajaran pembangkit listrik mikrohidro dapat meningkatkan kemampuan berpikir kritis peserta didik. Berdasarkan mean \pm SD diperoleh bahwa rata-rata nilai postes $(81,44)$ lebih tinggi daripada nilai pretes $(61,41)$, sehingga dapat disimpulkan bahwa kemampuan berpikir kritis peserta didik semakin baik atau mengalami peningkatan. Sesuai dengan Masek dan Yamin [8], proses pembelajaran Project Based Learning secara aplikasi mendukung pengembangan berpikir kritis peserta didik. Adanya umpan balik dari peserta didik dan kemampuan pemaparan dari proyek yang dilakukan menjadikan stimulus bagi peserta didik untuk mengembangkan kemampuan berpikir kritis. Namun demikian, peran fasilitator dalam 
melakukan mediasi dengan peserta didik, terutama dalam memicu pemikiran meta-kognitif sangat diperlukan.

\section{Model pembelajaran Project Based Learning} memberikan pengalaman dan pengetahuan baru bagi peserta didik karena secara tidak langsung belajar menjadi ilmuan, melakukan tindakan secara ilmiah dalam melaksanaan suatu proyek, yaitu mulai dari merumuskan permasalahan, menentukan prosedur, menentukan alat dan bahan yang dibutuhkan, melakukan penyelidikan, mendesain dan menciptakan produk, mempresentasikan atau komunikasikan produk sebagai hasil dari proses penyelidikan, dan melakukan diskusi kelompok. Aktivitas tersebut tentu saja memberikan stimulus pada peserta didik untuk meningkatkan sikap positif terkait pembelajaran sains. Dominasi peserta didik dalam pembelajaran pada model pebelajaran berbasis proyek akan mengembangkan beberapa aspek sikap terkait sains yang lain, yaitu menyenangi pelajaran sains, tidak menjadikan pembelajaran sains menjadi mata kuliah yang menakutkan, dan melatih peserta didik untuk kritis terhadap permasalahan yang ada.

Media mikrohidro dipilih tidak hanya membuat siswa memamahi materi Fisika Teknik tentang kelistrikan, namun menuntut peserta didik berpikir kritis tentang pemanfaatan sumber daya di lingkungan sekitar untuk menjadi energi yang bernilai guna. Sesuai dengan Undang-Undang Nomor 12 Tahun 2012 tentang Pendidikan Tinggi dalam pasal 13 ayat 2 yang menyatakan bahwa mahasiswa secara aktif mengembangkan potensinya dengan melakukan pembelajaran, pencarian kebenaran ilmiah, dan/atau penguasaan, pengembangan, dan pengamalan suatu cabang Ilmu Pengetahuan dan Teknologi untuk menjadi ilmuwan, intelektual, praktisi, dan profesional yang berbudaya.

\section{KESIMPULAN}

Hasil penelitian menunjukkan adanya peningkatan kemampuan berpikir kritis peserta didik setelah dilakukan proses pembelajaran dengan menerapkan model Project Based Learning. Berdasarkan hasil perhitungan $\mathrm{N}$-gain ternormalisasi diperoleh rata-rata kenaikan hasil belajar dari 20 orang siswa adalah 0,45. Nilai tersebut menunjukkan bahwa kenaikan hasil belajar peserta didik dalam kategori "sedang". Hasil analisis data dengan uji $t$ (t-test) menunjukkan bahwa terdapat perbedaan nilai kemampuan berpikir kritis peserta didik sebelum diberikan pembelajaran dengan nilai kemampuan berpikir kritis peserta didik setelah diberikan pembelajaran dengan model Project Based Learning. Nilai rerata mean diperoleh bahwa rata-rata nilai postes $(81,44)$ lebih tinggi daripada nilai pretes $(61,41)$, sehingga dapat disimpulkan bahwa kemampuan berpikir kritis peserta didik semakin baik atau mengalami peningkatan.

\section{Saran}

1. Pendidik harus terus berupaya menstimulus peserta didik untuk meningkatkan kemampuan berpikir kritis dengan berbagai model pembelajaran yang relevan. Misalnya model pembelajaran berbasis proyek dan studi kasus yang terintegrasi dengan proyek-proyek dalam upaya mengatasi permasalahan lingkungan ataupun mengangkat kearifan lokal.

2. Pendidik harus terus mengevaluasi tujuan pembelajaran dan menggabungkan berbagai strategi sesuai pembelajaran dan penilaian ke dalam kurikulum dalam rangka mencapai tujuan pembelajaran.

3. Kegiatan pembelajaran berbasis proyek sebaiknya diupayakan untuk dikembangkan dalam bentuk kegiatan 
seminar hasil dan pelatihan yang mengakomodasi peserta didik untuk mempraktekkan.

\section{DAFTAR PUSTAKA}

[1] Kemendikbud. Lampiran Permendikbud Nomor 81A Tahun 2013 Tentang Implementasi Kurikulum Pedoman Umum Pembelajaran. Jakarta: Kementerian Pendidikan dan Kebudayaan RI; 2013.

[2] Birgili B. Creative and Critical Thinking Skills in Problem-Based Learning Environments. Journal of Gifted Education and Creativity. 2015; 2(2): 71-80. Terdapat pada: https://eric.ed.gov/?id=ED563985

[3] Mergendoller JR, Markham T, Ravitz J, and Lahmer J. Pervasive Management of Project Based Learning: Teacher as Guided and Facilitators. Editor: Evertson CM dan Weinstein CS, Handbook of Classroom Management Reseach, Practice dan Contemporary Issues. New Jersey: Lawrence Erlbaum Associates Inc; 2006.

[4] El-Shaer A dan Gaber H. Impact of problem-based learning on students critical thinking dispositions, knowledge acquisition and retention. Journal of Education and
Practice. 2014; 5(14): 74-85. Terdapat pada: http://www.iiste.org/Journals/index.php/JEP/a rticle/view/12992

[5] Sulaeman S dan Jaya RA. Perencanaan Pembangunan Sistem Pembangkit Listrik Tenaga Mikro Hidro (PLTMH) di Kinali Pasaman Barat. Jurnal Teknik Mesin. 2015; 4(2): 90-96. Terdapat pada: https://ejournal.itp.ac.id/index.php/tmesin/arti cle/view/269

[6] Sugiyono. Metode Penelitian Kuantitatif Kualitatif \& RND. Bandung: Alfabeta; 2010.

[7] Hake RR. Interactive-Engagement Versus Traditional Methods: A Six-Thousand-Student Survey Of Mechanics Test Data for Introductory Physics Courses. American Journal Physics. 1998; 66(64). DOI: http://dx.doi.org/10.1119/1.18809

[8] Masek A dan Yamin S. The effect of problem based learning on critical thinking ability: a theoretical and empirical review. International Review of Social Sciences and Humanities. 2011;2(1): 215-221. Terdapat pada: http://irssh.com/yahoo site admin/assets/doc s/19 IRSSH-126-V2N1.51195951.pdf 